\title{
Factors of integration of education system in effective sustainable development strategy
}

\author{
Tetyana Zhyzhko ${ }^{1, *}$, Nataliia Krokhmal $^{2}$, Olha Horpynych $^{3}$, Natalia Riezanova ${ }^{4}$ \\ ${ }^{1}$ Doctor of Sciences (Philosophical), Professor, Professor, Department of Management, Information \\ and Analytical Activity and European Integration of the National Pedagogical Dragomanov \\ University, Kyiv, Ukraine \\ ${ }^{2} \mathrm{PhD}$ in Philosophy, Associate Professor, Professor, Department of Management, Information and \\ Analytical Activity and European Integration of the National Pedagogical Dragomanov University, \\ Kyiv, Ukraine \\ ${ }^{3} \mathrm{PhD}$ in Philosophy, Associate Professor, Associate Professor, Department of Sociology of the State \\ University of Telecommunications, Kyiv, Ukraine \\ ${ }^{4} \mathrm{PhD}$ in Philosophy, Associate Professor, Associate Professor, Department of Political Science and \\ Law of the National University «Zaporizhzhya Polytechnic», Zaporizhzhya, Ukraine
}

\begin{abstract}
From the very first day of his birth until his death, man is under the watchful eye of society. Economic or industrial relations form the basis of society and social life. But, according to most sociologists and philosophers of the XX-XXI centuries, for thousands of years there were other, not less important laws and relationships that impeccably «guide» human actions - these are moral values. Thus, economics, morality and politics are so closely intertwined in modern post-industrial society that it is simply impossible to separate them from each other. After all, today «man as a person» and «man as a citizen» define two main directions of progress of human existence: the direction of development of the «inner world» of man - the formation of new moral and psychological principles of existence; the direction of development of the «external world» of man - the formation of new economic, political and socio-psychological principles of existence. But a person's freedom of action in a post-industrial society does not absolve himself of responsibility to society. Responsibility itself keeps a person from uncontrolled intentions.
\end{abstract}

\section{Introduction}

The supporters of a technocratic managerial, psychological and pedagogical approach to economic and social activity emphasize the presence of a deep psychological and moral crisis of modern civilization. They see its manifestation in the absence of discipline, in the people's indifference to the state and social good. They generally transfer the blame for the fall of these qualities to the authors of the educational concepts that have gained popularity, which are based on the self-realization of the individual, to satisfy his versatile needs (existentialism, positivism, etc.). In their opinion these concepts lack a scientific approach to understanding economic, social and statist (the so-called «state-centric») behavior.

To change the current situation, the supporters of neobehaviorism consider it necessary to create a system of management and education that is controlled by the interests of the modern state, industrial society, social and cultural development, and the implementation of the tasks of the scientific and technological revolution. «Society has always emphasized the

\footnotetext{
Corresponding author: ludmilasemyonovnaberdyansk@gmail.com
} 
dependence of its well-being on a vital and effective educational system. School and educational institutions should stop the degradation of public life and awaken a sense of mutual trust and cooperation among people» [1]. But to achieve this, the education and management systems must rely on science, on a wide range of knowledge about a person, use modern methods of researching of a person's interests, needs, abilities, factors that determine his behavior.

In addition, the introduction of scientific methods in the field of management and education should have a clear focus and value attitude.

Social pedagogy and social and managerial psychology of neobehaviorism, as a model of economic and social activity, which is primarily based on the ideas of behaviorism - it has become a methodological basis for the design of technocratic concepts of management, of the social and economic activity, social development, which occupy dominant positions in developed industrial countries, especially in the USA. It mainly relies on the concept of «technology of behavior» by the founder of modern behaviorism and, in general, on behaviorist psychology, management and philosophy of education, pedagogy of neobehaviorism.

\section{Research methodology}

Represented by E. Morris, M. Black etc ideas of neobehaviorism in their direct application to the problems of education are shared by a group of economists, philosophers, educators and psychologists. The followers of this idea reject personal self-development as the main goal of education as they consider this to be the main reasons of social and moral crisis. They follow the belief that a person is a learning and modifiable creature; it is during the process of learning when all the norms of his behavior are developed. The effectiveness of training is achieved by introducing the achievements of science and technology, experiment into the system of formation and education. Thus, this approach seems to be strictly «scientific» and rationalistic, the influence of these concepts among certain circles of society, including the scientific intellectual society, is ensured.

With this approach, management and education are subordinated to a purely utilitarian goal, primarily to increase labor productivity, as well as to acquire skills for mastering moral norms, principles of the social environment and exact, unquestioning obedience to these principles. The main means of implementing such social and economic and psychological and pedagogical program is tight control by the state and the social environment with the help of the «reinforcement» mechanism, i.e. the systems of rewards or punishments for the slightest deviations from a given program. This mechanism (especially its repressive side) is designed to ensure the trustworthiness of people, especially young people, to form the sense of need to obey the dominant ideologemes, norms, requirements, which quite often (especially in societies of a transitive or transitional type) reflect the interests of the ruling elite.

Relying on the system of «reinforcement» technocratic concepts pay special attention to creation of voluntary submission of the individual to these requirements and thereby to the achievement «harmony» between the consciousness of the individual and society. However, they interpret this very «harmony» only as serving to the abstract and general ideals of the state and nation while bringing the detriment to personal interests, and the sense of responsibility of the individual - is only the manifestation of loyalty to the ideological or traditionalist values of society and the attributes of power. The ideas of economic and psychological technocratic concepts have found their practical implementation in various forms of «behavioral modifications», which often have an explicitly or implicitly repressive character. These methods of «education» are being 
introduced into the system of administrative and industrial management, social management, upbringing, education, organizations and enterprises, educational institutions.

There is no need to prove that management and education that use such methods acquire the character of the «human-building» industry planned by the ruling class; they start being similar to the social and economic training of people who are absolved from moral motives and criteria [2].

\section{Results of the research}

The technocratic approach to man and his social and economic essence is perceived differently by theorists and practitioners. In academic circles, including specialists in the field of behavioral management, production management, philosophy of education, the technocratic ideas are largely subjected to rather harsh criticism.

As for the processes of management and social upbringing, the behavioral norms and the technique of «reinforcement» formulated by behaviorism are still widely used there. The fact is that methods of modifying behavior in the style of «production regulation» are very convenient for the formation of people with predetermined abilities, economic stereotypes and political standards, moral qualities, with certain moods, ready to faithfully serve the government and the ruling elite. This factor is especially relevant for societies of the post-totalitarian, «transitional type», in the development of which there is a constant danger of transformation into a repressive oligarchic-clan system with illusory, declarative «human rights» and underdeveloped civic consciousness.

Besides, these methods are used by government agencies, conservative social institutions to control dissenters, to adapt their behavior to the requirements of a particular type of society, economic and political system. If there is a discord between the individual and the social and economic environment, they - the government and conservatives of neobehaviorism - seek to hide its true nature and argue that it all comes down to the behavioral problem that can be solved by a new procedure («reinforcement») - writes the American expert on education C. Bowers [3], he reveals the social content of the use of the ideas of neobehaviorism in social and economic practice. Agreeing with Bowers, professor W. Feinberg from Illinois University notes that the influence of behaviorism ideas on the social, economic and political system is explained not only by their truth or scientificity. It is «due to the fact that behaviorism creates common, international norms and procedures that are essential for the re-creation of social roles defined by modern corporations and by the capitalist state» [4].

Sympathisers of neobehaviorism are trying to free the process of education from value approaches, subordinating it to the so-called «rational thinking». This encourages them to focus on B. Skinner's theory, the main component of which is a mechanism of control and self-control, aimed not at the comprehensive development of personality, but at educating socially obedient people. A dangerous result of the practical implementation of these ideas can be not only the formation of a socially tolerant person, but also a «one-dimensional» non-critical individual who identifies his thinking and behavior with the existing political and economic regime.

From the very first day of his birth until his death, man is under the watchful eye of society. Economic or industrial relations form the basis of society and social life. But, according to most sociologists and philosophers of the XX-XXI centuries, in society for thousands of years there were other, no less important laws and relationships that impeccably «guided» human actions - these were moral values. Thus, economics, morality and politics in modern post-industrial society are so closely intertwined that it is simply impossible to separate them from each other. After all, today «man as a person» and «man as a citizen» define two main directions of progress of human existence: 
1) the direction of development of the «inner world» of man - the formation of new moral and psychological principles of existence;

2) the direction of development of the «external world» of man - the formation of new economic, political and social and psychological principles of existence.

Paying attention to the negative consequences of the scientific and technological revolution that man encounters in the modern world, including various forms of subordination of the individual and his freedom, neobehaviorism sees the source of this evil in man himself, as if he is highly irrational in nature. The manifestation of his extreme individualism is that he is not interested in both near and far, refuses all the conquests of mankind and does not think about the future. But he is obsessed with one idea - that is he seems to have freedom and dignity. Hence the neobehaviorism suggests that the solution to all difficult modern problems should be sought not in the sphere of production or social relations, but in the sphere of behavior. They say the main problems the world faces today can be solved only if human behavior improves. To achieve this, it is necessary to create a special science of behavior, which Skinner calls «behavioral technology» [5]. In its framework, neobehaviorism seeks to develop an approach to man that will program behavior and manage public life, which will lead to the creation of an «effective civilization» where people will finally be happy.

Two guidelines of «behavioral technology» played a primary role as methodological prerequisites for technocratic concepts of education: Skinner's understanding of human nature and his theory of reinforcement. To create a science of behavior, Skinner states that it is necessary to abandon the pre-scientific view of human nature that is characteristic of modern America and Euro-Atlantic civilization in general: «beyond freedom and dignity». Skinner (following by neobehaviorism) discards any system of ethics, declaring it to be unscientific. His goal is, with the help of «behaviorist engineering», to construct a «controlled individual» who is comfortable enough to the «total society». That is why Skinner and neobehaviorism abandoned the notion of the free choice of actions by an individual accepted in ethical science, as if they did not seem to correspond to human nature, instead they proposed to replace them with the notion of «formed automatic skills». The latter, in their opinion, are not only effective in terms of controlling the behavior of the individual, but also increase the chances of survival of modern civilization. Basing on this, another concept is introduced into the theory of neobehaviorism - «automatically correct behavior», which is tried to be considered as a basis of different models of social, economic and political actions that meet the interests of public manipulators and controllers. «Skinner's utopia is called a late recurrence of repressive totalitarian pseudoscience, if, unfortunately, it wouldn't agree with the mood of certain social groups in today's society» [6]- writes the American Sociologist D. Benson.

By releasing man from morality, this theory contributes to the intensification of the moral crisis in modern industrial society.

Skinner's ideas impress those followers of scientific and social thought, economic and political practice, who try to use them to form the ideological standards and norms of behavior necessary for the state and public system. The American Philosopher H. Wheeler described Skinner's theory «as an important contribution to psychology and social science over the past 50 years», believing that «it can serve as a scientific criterion for assessing the social content of the introduction of operant behavior into social practice» [2]. One of the areas of public practice, where the «behavioral technology» is widely used, is the management of different levels and forms, the field of education. The proponents of the introduction of Skinner's ideas in the field of management and education see them as an important factor not only in establishing a strict order in the state and society, but also in the development of individual freedom. In particular, this idea is defended by the American Researcher V. Pattern. He evaluates the control over people's behavior with the help of the 
ideas of neobehaviorism as strictly scientific, morally neutral, and therefore, quite valuable and able to ensure order and freedom, both for society and for the individual. According to Pattern, it is possible to solve important humanistic problems with the help of such control.

The ideas of neobehaviorism are used both to substantiate the principles of management, education, and to develop methods for their implementation. In both cases, the proponents of strict control over human behavior are so closely associated with behaviorism that their theoretical statements clearly follow its terminology. For example, V. Pattern emphasizes that the concept of social control, introduced by Skinner, should take a leading place in the management and theory of education, because only it can help show people how they should behave in a normal situation. "The general order of things may change, but the very behavior brought up by social control must be imperative in nature» [7]. But at the same time the concepts of management and education, which are based on the idea of strict behavioral control, lose their unique features in comparison with the psychology and ethics of behaviorism. This can be traced primarily by the way how the main purpose of education is determined.

Following Skinner's thesis that modern society should be based on «rational thinking», the proponents of technocratic concepts focus on educating a person whose ideal would meet the requirements of industrial society. By influencing different layers of the human psyche, they seek to nurture not a holistic personality, but a scientifically oriented, technically educated person who is destined to remain infantile in matters of general culture and morality. Despite the high level of professional specialization, such a person is not capable of independent reflection on social and moral problems; he easily succumbs to pressure from the social environment. His emotions and feelings are strictly subjected to the sharp power of the mind and are used as a means of intensifying production activities and of his strictly technical thinking level raising.

The proponents of the technocratic orientation hold the view that the family, secondary and higher educational institutions should not make any significant changes to the existing system of education. They prescribe to these institutions only the function of transmitting of dominant values, carrying out the socialization of the individual in order to intellectually and morally educate citizens who are able to function productively in society, responding to the ideas of technocrats about the «good citizen».

It should be a citizen «prosperous and who supports the system, accepting the rights and responsibilities of a democratic society, a patriot of his community and state» [2]. Therefore, all institutions, executing power, education, must adapt the individual to the ideologies of the state, norms and standards of society, to educate him in the spirit of the idea of the highest good, service to society and the state. They oppose this orientation to the «self-realization» of the individual, seeing in it one of the main reasons for the moral degradation of the individual and society, the manifestation of selfishness and indifference to the interests of others and society as a whole.

The changes in moral values in the XX-XXI centuries occur in the direction of softening the regulatory framework of society. Man is gradually relieved from many social obligations that have been imposed on him over the centuries. And thinkers call on modern society to be loyal to man. In particular, it is noted that we must get rid of the concept of universal moral responsibilities, and turn to the interests of man [8]. But the freedom of action of man in post-industrial society does not relieve him from responsibility to society. Feelings of responsibility keep a person from the uncontrolled intentions. But these feelings arise only under the condition of the «principle of justice as fairness».

The «principle of justice as fairness» was proposed by J. Rawls. In his works he explored a complex range of factors that provide the mechanism of social balance in society. According to J. Rawls, in modern post-industrial society, the «principle of justice as fairness» is implemented on two levels - ethical and political [9]. At each of these levels, 
human dignity is protected in a certain way. But, if at the first level, the dignity of a man as a person is protected, at the second - the dignity of a man as a citizen.

Advocating normativity instead of «absolute freedom» of personality, the supporters of technocratic orientation do not mean to instill in people a conscious attitude to the norms and principles of morality, which include understanding of the objective basis of these norms and principles, their moral and social content as well as their self-assessment. And for this purpose a man should be able to distinguish the given and obligatory, search of ways of confirmation of those norms of behavior which promote establishment of humane relations between people. However, in technocratic concepts of education, sometimes the focus on a value-based approach to actions and phenomena is replaced by the requirements of adaptation of the individual to existing political, ideological and moral norms. And for the adaptation you are not required the conscious reflection on the nature of these norms and the consequences they may have for personal and public good. The only argument that can be used as «evidence» of the necessity and expediency of the individual adapting to the existing norms is the fear of a moral crisis, the roots of which, as already noted, the neobehavioral technocrats see in individual freedom only.

The proponents of the neobehaviorist concept believe that, for example, by defining «responsibility» as the voluntary adherence of the individual to the requirements and norms of the social environment, they, however, do not associate it with the level of consciousness, his goals, ideals, without which voluntary, conscious attitude to social requirements is simply impossible [5].

In fact, by technocratic thinking the responsibility is compared to obedience and submission to dictation. But in this case it loses its moral content, because man relies more on the instinct of self-preservation than on the mind. Of course, responsibility is especially important in the field of production, especially during the scientific and technological revolution. It may seem that, by paying attention to this problem, the supporters of the technocratic approach express an important idea about the connection between education and labor, about the moral significance of labor. But the attitude to labor acquires a real moral significance only when a person works conscientiously not only for the satisfaction of his own needs, but also for the sake of society, for the common good. But the alienated labor cannot become one. Democratic social and psychological conditions in society, the state and the economy can be created through moral psychology. According to J. Rawls, moral psychology is not a psychology that begins in the science of human nature, but the moral psychology that is derived from the political concept of justice as fairness.

When the neobehaviorist supporters of technocratic management and education speak of the need to develop active human activity, especially in the sphere of production, they do not care of the interests of each individual, a huge mass of individuals and groups, but only of the interests of a social system, the state as a whole, the needs of modern industrial societies that need a constant increase in productivity. At the same time, education should not advertise the true meaning and purpose of the qualities that are formed in students. Moreover, it is designed to separate the motives of the need of human productivity increase, as well as his general activity from himself. And to achieve this goal, the authoritarian system of management and education is helped by the neobehaviorist concept, which teaches people to «consider their activity as actions that are ordered by the social system in strict behavioral terms» [6].

The realization of the goal of power, control and education, which is considered by neobehaviorism as manipulation of people, needs appropriate methods in various forms of training, behavior modifications based on reinforcement factors. To this end, special methods of encouragement and punishment have been developed for the upbringing process, with the help of which the main goal is achieved - the formation of obedient people. This task should be solved by the administration, managers and teachers, who are 
the main figures in the behavior modification system. Anyone who becomes a manager, teacher, educator, not only has the right, but is also obliged to modify the behavior of his subordinates. The neobehaviorism system believes that children come to school without the necessary social and cognitive skills for productive functioning in the circle of adults. The behaviorists see in the pupils only the individuals who are amenable to manipulation, without taking into account their inner world and their individual characteristics. They consider it necessary to explain the inner world of a person in terms of social reinforcement, replacing, where it is possible, the needs of the human soul with various kinds of sanctions. Therefore, in any disorder between the personality and the social environment, neobehaviorists see only a behavioral, but not social, economic and political problem, which, as they believe, can be solved by forming a new reinforcement procedure.

The process of management and education, which develops according to the recommendations of the supporters of neobehaviorism, is focused on creating the atmosphere of impersonal relations and pansophy, and to direct the norms of behavior along a path that would completely exclude the possibility for people to self-control over the received requirements, knowledge and mode of their behavior. The neobehaviorist managers are primarily concerned with how to make the entire behavior modification process scientific. At the same time the science turns into a weapon of power, into a means of destroying the personality. The manager, the teacher, takes on the role of a faceless technocrat who seems to simply rely on science to identify the best that is inherent in everyone. But this ideological position is being carefully hidden. Subjects are only aware of the connection between their attitudes as those who have bureaucratic power, and the incentives from society.

Behavior modifiers want to embrace by their control as wide circle of people as possible in order to ensure its effectiveness in terms of transforming them into mindless robots who accept existing law and power as invariable and necessary. The essence of control is in producing a certain psychological attitude in a person, the readiness, under the fear of punishment, to adapt to any requirements of the social and political and economic system, to suppress his desire for self-expression, and to form conformal behavior. Such management and nurturing is not just similar to the social mechanism by which knowledge and relationships between people are controlled. It means that this is such a powerful control, which covers all spheres of life of individuals, due to which relations between people become impersonal and therefore purely mechanical, selfish and even cruel. Objective moral norms, rules that have been developed by humanity, under these conditions are completely alienated from the individual. Naturally, the progressive representatives in the field of economic and social management, social thought, protest against the development of technological methods and methods of influencing a person and their introduction into the management process, rightly seeing this as a factor expanding the conditions and forms of manipulating a person, his behavior.

A modern western-style industrial society is a society that constantly renews its technological base. But technical and scientific discoveries, according to D. Bell, are carried out not for the sake of simple human interest, but mainly for the preparation of the material base of society for the conquest of new social goals. That is why the model of social reality of post-industrial society has been formed on the principles of the concept of «social technology». This concept arose with the aim of predicting new forms or new technologies of social organization, which was called «social modernization» of society [10]. Socialization of a creative person takes place both at the professional level and at the level of general communication connections. Indeed, according to D. Bell's definition, postindustrial society is a society based on «a game between people, in which intellectual technology grows against the background of machine technology» [11]. 


\section{Conclusion}

In order to adapt a person to a social system, neo-behavioural technocrats consider it necessary to instill certain moral qualities, and first of all, the sense of responsibility as the main condition for the viability of the social system. Particular importance is given to responsibility and discipline in the labor process. Accordingly, the theorists of neobehaviorist technocratism recommend teaching young people in secondary and higher educational institutions to keep strict discipline, to cultivate in them the habit of persistent work, to solve difficult tasks, so that everyone can occupy a certain place in society in the future. It is undoubtedly known that the presence of these qualities is necessary for any specialist, wherever he works. The current level of scientific and technological progress requires from an employee not only high qualifications, but also an understanding that the smallest deviation from production technology, from the performance of their functions, violation of social discipline and safety measures can cause irreparable damage to both the enterprise and society. It is important that the upbringing of these qualities is not formal, a «tribute» to the requirements of the environment, supported by the fear of punishment. This should be an integral attribute of a person's moral essence, an internal, and, therefore, a free imperative of his actions.

Still, one should not assume that revealing the manipulative orientation of technocratic concepts, thereby generally denies the importance of factors of social reinforcement (encouragement and punishment of people's actions) as one of the elements of the influence of educational institutions on personality behavior. But the positive value of social reinforcement, firstly, is associated with the goal to which it should be subordinate - with the desire for the moral growth of the individual and society.

In a developed democratic society, more progressive forms of relations between man and society, the state, the economic structure and mental landmarks must be found; in the XXI century man should not blindly obey the general rules of behavior, but take an active part in the process of social and economic creativity. The purpose of the activity should be clearly understood by both managers, educators, and the managed, educated. A person since childhood, and later in adolescence, through his personal experience, tests most of the social norms and economic standards that society offers him. He cannot accept those norms that limit his right to freedom of personal life. The effectiveness of social and economic reinforcement depends on the degree of trust and respect of the individual to the power, management and educational structures, institutions of society and specific people whom society has entrusted to carry out the management process.

\section{References}

1. S. Clement, Handbook of Education Technology (Steven Hackbarth Books, London, 2014)

2. H. Wheeler, Beyond the Punitive Society. (Hackett Publishing Co, San-Francisco, 2013)

3. C. A. Bowers, Teach. Coll. Rec. 79, 35 (2017)

4. Feinberg, Behavioral Theory and Education (Prentice-Hall, Boston, 2012)

5. B. Skinner, History and Human Behavioral (Macmillan, New York, 1995)

6. D. Benson, Immoral America: Beyond Freedom and Dignity (Caplan A.Z. Press, New York, 2018)

7. V. Pattern, Social Control and Human Engineering: A Framework for Humanistic Decision (University Press, Bangor, 2011)

8. L. Scoot, International of Norms (The Harvard International Press, Harvard, 2016)

9. J. Rawls, Political Liberalism (Essential, 2000)

10. V. Zinchenko, Social Philosophy of Management and Education in the Institutional 
Dimension of Global Development (K. Lyuksar, 2011)

11. D. Bell, The Coming Post-Industrial Society. Experience in Social Forecasting (M : Academia, 2019) 